\title{
CURRENT ISSUES RELATED TO ACCESS AND USE OF INFORMATION ON EX SITU CONSERVATION OF PLANT GENETIC RESOURCES IN THE REPUBLIC OF MOLDOVA
}

\section{Gabriela ROMANCIUC}

Institute of Genetics, Physiology and Plant Protection, Chisinau, Republic of Moldova

Corresponding author: Gabriela Romanciuc, e-mail: gabriela.romanciuc@gmail.com

DOI: $10.38045 /$ ohrm.2020.1.17

UDC: 631.52:004(478)

Keywords: conservation, gene bank, plant genetic resources, information system, documentation.

Cuvinte cheie: conservarea biodiversității, banca de gene, resursele genetice vegetale, sistem informațional, documentarea.
Introduction. The rapid development of information technologies has provided challenges and opportunities for effective documentation of plant genetic resources (PGR). Access to information on PGR is essential for their conservation and sustainable utilization.

Material and methods. Information System on PGR in Republic of Moldova - ReGen was created to manage the data on PGR conservation at the national level and represents unified system that includes three basic functional blocks: ex situ, in situ/on-farm.

Results. The study resulted in an analysis of existing situation on information management of PGR ex situ conservation at national level, as well it highlighted the major challenges and constraints in this area. The priorities for ex situ conservation activities and related information were proposed.

Conclusions. An integrated approach of ReGen information system seems to be the most adequate way to increase the possibility to manage more efficiently the existing information about germplasm collections at the national level, make more easily and available the data for users and use the appropriate conservation strategies.

PROBLEME ACTUALE PRIVIND ACCESUL ȘI UTILIZAREA INFORMAȚIEI CU REFERIRE LA CONSERVAREA EX SITU A RESURSELOR GENETICE VEGETALE ÎN REPUBLICA MOLDOVA

Introducere. Dezvoltarea accelerată a tehnologiilor informaționale a oferit noi provocări și oportunități pentru documentarea eficace a resurselor genetice vegetale (RGV). Accesul la informațiile despre RGV este esențial pentru conservarea și utilizarea durabilă a acestora.

Material și metode. Sistemul informațional cu privire la RGV din Republica Moldova ReGen a fost creat pentru a gestiona datele referitoare la conservarea RGV la nivel național, reprezentând un sistem unitar care include trei blocuri funcționale de bază: ex situ/in situ/on farm.

Rezultate. Studiul s-a finalizat cu analiza situației existente în domeniul gestionării informațiilor a RGV conservate ex situ la nivel național, a evidențiat provocările majore și constrângerile din acest domeniu. Sunt propuse prioritățile pentru activitățile de conservare ex situ si informațile aferente acestora.

Concluzii. $O$ abordare integrată a sistemului informațional ReGen este cea mai potrivită cale de gestionare eficientă a informațiilor aferente colecțiilor de germoplasmă vegetală existente la nivel național, ceea ce facilitează accesul utilizatorilor la datele de interes, precum și adoptarea de strategii de conservare adecvate. 


\section{INTRODUCTION}

Plant genetic resources for food and agriculture (PGRFA) constitute an integral component of biodiversity and are crucial for sustainable agricultural production.

The conservation of PGRFA in gene banks and the promotion of their sustainable use are essential for ensuring global food security and overcoming growing environmental challenges and climate change. PGRFA can be defined as "genetic material of plant origin of actual or potential value for food and agriculture" (1), that comprise modern cultivars, breeding lines and genetic stocks, obsolete cultivars, ecotypes, landraces (LR), crop wild relatives (CWR), as well as weedy races and primitive forms of crops (2). They are the raw material for breeding new plant varieties and constitute a reservoir of genetic diversity.

Today, the problem is that the genetic resources are not managed effectively, and the loss of important germplasm is documented. Ex-situ collections are currently kept in about 1750 gene banks worldwide, many of which are in poor physical condition and continue to be degraded as a result of insufficient funding. Another problem is that many of the accessions are duplicates that are a waste of valuable resources. Besides this, poor publicly available information about the stored materials was attested (3). In this context can be mentioned that despite the availability and accessibility of PGR the availability of information and the easy access to it are a necessary utilization prerequisite.

Information access is the ability to identify, retrieve, and use information effectively. Access to information is vital for social, political, and economic advancement. Traditionally, information has been disseminated in a variety of formats that have been widely accessible. However, advances in computer technology revolutionized information access, making vast stores of business, education, health, government, and entertainment information accessible on the World Wide Web (4).

Access to information on PGR is essential for their conservation. The importance of information in conservation and sustainable use of genetic resources is recognized in various global conventions, such as the Convention of Biological Diversity (1992) - Article 17: Facilitate the exchange of information relevant to the conserva tion and sustainable use of biological diversity; Global Plan Action (GPA 1 - 1996 and GPA II 2011) - Priority Activities 17 \& 15: Constructing and stren-gthening comprehensive information systems for PGRFA and International Treaty on Plant Genetic Resources for Food and Agriculture - ITPGRFA (2001) - Article 17: Contracting Parties shall cooperate to develop and strengthen a global information system to facilitate exchange of information...related to PGRFA.

The basic element of PGR data management in gene banks is the documentation systems. Nearly all gene banks created their own documentation system and computerized the information about their germplasm. The complexity of these systems varies widely and depends on the size of the collection, technical support, funding, and level of integration in PGR community etc. Small collections that allow simple documentation systems used Excel spreadsheets. However, once the collections grow, database management issues such as data integrity, data security or data processing become more important. Thus, more specialized computer database management software programs (MySQL, Access or Oracle) need to be used (5).

One of database software programs cover only passport data some include genebank management information, and others include characterization and evaluation (C\&E) data (data on the distribution and use of the germplasm or other types of related information). Currently, information on PGR is concentrated on passport information that is usually rather similar, and consists of stand ard fields such as scientific name, common name, accession (variety) name, accession number, maintaining institute and country of origin etc. However, germplasm users are usually more interested in the germplasm traits. They would like to be able to select directly the material for the resistant, high yielding, drought tolerant, early maturing, and bright green or sweetest accessions. This information represents the evaluation and characterization data (C\&E) and is rarely available in computerized forms of genebanks, so the information interpretation is difficult. Currently molecular marker data, information about QTLs and genes are becoming widely available. This is an important source of information for researchers, genebank staff, and plant breeders for identifying appropriate germplasm for breeding purposes. Farmers and 
other users are also interested in genebank activities (6).

Currently, efforts are being made by the scientific community for promotion of open access to scientific information. Open access was initially developed for publications and journals, but now the concept is being extended (7). The accepted definition comes from the Berlin Declaration on Open Access, which states: "We define open access as a comprehensive source of human knowledge and cultural heritage that has been approved by the scientific community. Open access contributions include original scientific research results, raw data and metadata, source materials, digital representations of pictorial and graphical materials and scholarly multimedia material." Open access initiatives offer a great opportunity to make PGR information accessible to anyone, at any time and any place $(8,9)$. Thus, the information can be accessed through various web page, database etc.

A lot of institutions are encouraged to put their data on-line, promote open access to PGR information, improve the conservation initiatives, and share the data on their germplasm collections.

Recently, many institutions that maintain germplasm collections put the information concerning their holdings online. The information at the accession/sample/species level can be available at the following level (10):

- Genebanks (N.I.Vavilov All-Russian Institute of Plant Genetic Resources (VIR), Russian Federation (www.vir.nw.ru/ data/dbf.htm), Centre for Genetic Resources, Plant Genetic Resources (CGN-PGR), the Netherlands (www.cgn.wur.nl/UK/CGN+ Plant+Genetic +Resources), Kew's Millennium Seed Bank, Wakehurst Place, UK (http://data.kew.org/ sid/about.html); Nordic Gene Bank (https:// sesto.nordgen. org/sesto/) etc.;

- National level (Informationssystem Genetische Ressourcen (GENRES), Germany (www.genres.de/pgrdeu), Japan National Institute of Agrobiological Sciences (NIAS) Genebank (www.gene.affrc. go.jp/ databases_en.php), USDA Agricultural Research Service, National Genetic Resources Program (NGRP), USA (www. arsgrin.gov), Nordic Countries (Denmark, Finland, Iceland, Norway, Sweden) (www. nordgen.org/ngb), National Inventory of Plant Genetic Resources for Food and Agriculture, Austria (www. Gen bank.at) etc.;

- Regional/sub regional (EURISCO European search catalogue (https://eurisco. ipkgatersleben.de/), ECPGR - European Cooperative Programme for Plant genetic resources with various Working Groups (https://www. ecpgr.cgiar.org/), The Southern African Development Community (SADC) countries (https://www.sadc.int/information-services) etc.;

- Global level (GENESYS (www. genesyspgr.org), Global Biodiversity Information Facility (GBIF) (https://www. gbif.org/) etc.;

- Information at a metadata level (FAO World Information and Early Warning System on Plant Genetic Resources for Food and Agriculture (WIEWS) - http://www.fao.org/ wiews/).

The information systems of these genebanks allow the user to browse, search and view information on their germplasm holdings.

According to Helmut Knüpffer (2007) the information on genebank collections belongs to other different levels (11).

- Collection-level data - metadata about genebanks and the germplasm collections they hold. Such information is available from the FAO WIEWS database etc.

- Accession-level data - information about individual accessions, especially passport data. Most PGR databases on various federation levels are based on accession-level data, such as individual genebanks (IPK'sLeibniz Institute of Plant Genetics and Crop Plant Research (IPK), Germany with on line information system GBIS, Nordic Gene Bank's information system SESTO, Germplasm Resources Information Network (USDA-GRIN https://www.ars-grin.gov/), central crop databases, regional or international "multi-crop" information systems (EURISCO, SINGER etc.). In biodiversity informatics, this is called 'unitlevel data'.

- Taxon-level data are related to (plant) species (or other taxa) as a whole, e.g., distribution information, uses, taxonomic classification. Examples of such databases related to crop plants are the taxonomic core of GRIN (U.S. Germplasm Resources Information Network) and Mansfeld's World Database of Ag- 
ricultural and Horticultural Crops etc.

The rapid development of information technologies has provided challenges and opportunities for effective documentation of plant genetic resources (PGR). Access to the data from documentation system maintained by different genebanks is not easy, due to several causes. In this context especially, incompatible information systems and languages used by genebanks could be mentioned. One of the simplest starting points in data and information on PGR is to make an existing data available on Internet. An important activity for genebank management has become developing web pages and making the information related to PGR available on-line. Improved access to Internet contributed to sharing the information related to PGR stored germplasm in the genebanks at the national, regional, and global levels $(12,13,14)$.

In the context of information management of PGR, a proper activity could result in more efficient application of GIS, statistical analysis, improved access to information and technologies, exchange of information, knowledge, best practices among the experts, enhanced communications through cost-effective electronic networks, construction of a common Internet platform for more efficient access to network national documentation systems, and links to global gateways for PGR information such as WIEWS, GENESYS, GRIN-Global, EURISCO, etc. These information systems were created for managing germplasmassociated information, facilitating genebank workflows, and providing a public interface for users to access and search for relevant information on plant genetic resources.

It is important to mention that, today, there is no single point of access to all genebank collections worldwide at the accession level, but germplasm data portals such as the WIEWS - FAO (World Information and Early Warning System on Plant Genetic Resources for Food and Agriculture), EURISCO (European search portal), numerous Central Crop Databases (CCDBs), the Nordic Genebank (NGB, Northern Europe), and the CGIAR's System-wide Information Network for Genetic Resources (SINGER) among others, show that distributed data on genebank accessions can be reached at global and regional level (15).

Easy accessible, high-quality and comprehensive information about PGRFA is essential for gene banks management.
This paper was focused on current issues of access to PGR data and described ongoing efforts to address these challenges in the Republic of Moldova.

\section{MATERIAL AND METHODS}

At national level, there is no program in the field of conservation and use of PGRFA. Thus, it is very difficult to analyze the real situation in area of documentation of PGR at national level, and the mechanism of access and sharing of information related to PGR do not exist. However, in order to monitor and manage the information of PGR at national level, ReGen system was created.

The present Information System on plant genetic resources in Republic of Moldova - ReGen has been developed since 2002 in the Center for Plant Genetic Resources of Moldova, now Laboratory for PGR of Institute of Genetics, Physiology and Plant Protection. For elaboration of ReGen was used programming language Visual Fox Pro 9.0. The system was set up for operation system Microsoft Windows 2000 and XP.

This system, created to manage the data on PGR conservation at the national level, represents unified information system that includes three basic functional blocks: ex situ (seed collections), in situ - maintenance of plant genetic resources in natural habitats, and data on crops and crop varieties grown on-farm.

When genetic resource is included into the collection, the national accession number is assigned to each accession as the unique identifier. This number is common for all three parts of ReGen.

Data on PGR in a relational database is organized into tables to record the passport, characterization and evaluation datasets. In tables, by indexation, certain relationships that allow fast search of necessary information can be established. Databases containing specific information can be managed separately, or linked when is necessary, to combine information from different database.

Top priority in database system was placed on the passport data as it contains fundamental information related to each germplasm managed by the Laboratory. The passport part includes the basic information on a genetic resource: taxonomy, cultivar name, country of origin, geographical coordinates, status of sam ple, year of 
acquisition, breeder and donor institution, etc. Many passport data are coded (institute code, donor code etc.) and all necessary coding tables are incorporated in the passport. Passport data correspond to Multi Crop Passport Descriptors (MCPD) elaborated by the Bioversity International and FAO, and revised in 2017.

Characterization and evaluation descriptors are crop-specific and are described according to Bioversity International, i.e. specific lists of descriptors for the genus with rules for the scoring of each trait.

ReGen is an important source of information for researchers, plant breeders, gene bank staff, farmers etc.

This system is not available on line due to the lack of adequate financial resources, but the datasets on germplasm conservation at the national level are included in big information system at international level such as EURISCO, WIEWS and the date on 6415 accessions conserved ex situ was reported in indicator 2.5.1. "Number of plant and animal genetic resources for food and agriculture secured in either medium or long-term conservation facilities" for Sustainable Development Goals. In 2017 National Information Sharing Mechanism (NISM) - FAO was established, and the data from our country were published in the NISM reporting system.

The aim of this research is the analysis of the existing situation in field of information management of germplasm collections conserved ex situ at national level and put in evidence the possible ways of accession to necessary data from existing ReGen documentation system for various purposes. Moreover, information sharing mechanisms between institutions holding ex situ germplasm collections will be highlighted in order to develop an integrated system for PGR documentation in our country.

\section{RESULTS}

In the Republic of Moldova there are five holder institutions of ex situ collections: Institute of Genetics, Physiology and Plant Protection (IGPhPP), through the Laboratory of PGR; ScientificPractical Institute of Horticulture and Food Technologies (SPIHFT); The Botanical Garden (Institute), Porumbeni Institute of Plant Growing and Selectia Research Institute of Field Crops.
The ex situ collection of the Laboratory for PGR is stored at medium-term conditions $\left(+4^{\circ} \mathrm{C}\right)$ and cover most crops that were cultivated in Moldova. The largest part of collection is presented by cereal crops such as wheat, maize, barley and triticale, vegetables such as tomatoes, chickpeas, soy beans, beans, and Vigna. These cultures are presented by varieties, hybrids, lines, mutants, local forms, etc.

In the Botanical Garden are preserved active collections and it ensures the medium-term conditions for seed. BG conserves ex situ about 10 000 plant species, of which 1200-1300 are food, fodder, aromatic, and spice species.

The collection of fruit crops is kept in the ISPHFT, being represented by apple, plum, apricot, pear, quince, cherry, cherry plum, walnut, almond, etc. The collection is represented by vast advanced/improved cultivars of local and foreign breeding materials, and an important role is assigned the old local forms.

The ex situ collection of grapevines is preserved in ISPHFT and is represented both by local varieties and new interspecific and intraspecific breeding.

Porumbeni Institute of Plant Growing stored a huge collection of maize, tobacco, etc. Thus, four types of collections can be mentioned: varieties collection -270 , mutants -250 , collection of lines - 300 and sources for cytoplasmic androstirility - 200. Zea mays and Nicotiana tabacum are the two species that focus on ex situ conservation at Porumbeni Institute.

The collection of the Selectia Research Institute of Field Crops is presented by the cereal crops wheat, barley, millet; leguminous and fodder crops-radish, soybeans, beans, sunflower, sugar beet etc.

It is important to mention that each holder institutions of ex situ collections have individual method and format to store the information on their collections. So, due to this fact the activities in field of PGR documentation are very difficult and access to this information is limited and the sharing of germplasm data is limited too. Only some of mentioned institutions such as Scientific-Practical Institute of Horticulture and Food Technologies, Porumbeni Institute of Plant Growing have been exported a small part of their datasets in ReGen. 
A lot of information is documented manually in the registers and only a small part of these data have been computerized. This situation is similar in practically all ex situ collection holders in the country.

Thus, at national level, the exchange of information on stored germplasm collections practically does not exist, and there is also no unique form for data storage.

The number of accessions conserved ex situ under medium-term condition in the Laboratory PGR for that are included in database is 4405 accessions. In particular, passport data were recorded, according to MCPD and only 4\% of characterization and evaluation data were doc umented.
The grapevine collection is fully documented. For this purpose, a grapevine database consisting of 1910 samples was developed. The entire Vitis collection is presented in the ReGen database by the passport data.

The collection of Porumbeni Institute of Plant Growing consists of 10,000 accessions. The total data on this impressive collection is not available for other institutions. In the ReGen database the data of 285 maize accessions from this institution are documented. Also, data on the fruit collection from ISPHFT are stored in ReGen and consist of passport data on 280 accessions of apple, apricot, plum, and pear, cherry (tab.1).

Table 1. The number of accessions stored in the institutions holding ex situ germplasm collections.

\begin{tabular}{|c|c|c|}
\hline Institution holding ex situ collections & Crop & Nr. of accessions \\
\hline \multirow{11}{*}{$\begin{array}{l}\text { Institute of Genetics, Physiology and Plant } \\
\text { Protection }\end{array}$} & Wheat & 487 \\
\hline & Triticosecale & 70 \\
\hline & Maize & 191 \\
\hline & Tomato & 671 \\
\hline & Chickpea & 101 \\
\hline & Soybean & 482 \\
\hline & Common bean & 408 \\
\hline & Pea & 169 \\
\hline & Pepper & 226 \\
\hline & Eggplant & 46 \\
\hline & MAP & 994 \\
\hline \multirow{2}{*}{ Porumbeni Institute of Plant Growing } & Maize & 10,000 \\
\hline & Tabacco & - \\
\hline \multirow{6}{*}{$\begin{array}{l}\text { Scientific-Practical Institute of Horticture } \\
\text { and Food Technologies } \\
\text { 1. Laboratory Gene pool, Breeding } \\
\text { and Genetics of fruit trees } \\
\text { 2. Laboratory Grapevine Genetic re- } \\
\text { sources and breeding }\end{array}$} & Apricot & 50 \\
\hline & Plum & 75 \\
\hline & Common pear & 20 \\
\hline & Apple & 104 \\
\hline & Cherry & 14 \\
\hline & Grapevine & 1910 \\
\hline \multirow{7}{*}{ Selectia Research Institute of Field Crops } & Wheat & 430 \\
\hline & Barley & 102 \\
\hline & Leguminous and fodder crops & 250 \\
\hline & Beans & 220 \\
\hline & Soybean & 550 \\
\hline & Sunflower & 600 \\
\hline & Sugar beet & 120 \\
\hline Botanical Garden (Institute) & Different species & 10,000 \\
\hline
\end{tabular}

The information on germplasm collections conserved within holder institutions are shared at national, regional, and international levels. Information on PGR ex situ collections at national level is available through EURISCO and WIEWS - FAO.
The European Search Catalogue for Plant Genetic Resources (EURISCO) provides information about 2,023,530 plant accessions comprising 6393 genera and 43,230 species preserved by almost 400 institutes, based on a network of National Inventories of 43 member 
countries (16). In 2019, the data of the National Inventory (NI) of Moldova, now comprising 6015 accessions, have been updated in EURISCO.

Many of the present data exchange mechanisms in use in the genebank community rely on laborious and repeated transformations of the original genebank data set into the agreed standard formats. In order to update the datasets on ex situ collections in EURISCO is need to comply with the EURISCO data exchange format, based on the Multi-Crop Passport Descriptors.

Thus, the information consisting of passport data from NI of Moldova, in accordance with the revised MCPD (2017) were updated.

The National Information Sharing Mechanism (NISM), on PGRFA in the country, has been established with the FAO support.

FAO WIEWS Reporting System, consisting of the 63 indicators from 18 Priority activities and reporting format, adopted by the FAO Commission on Genetic Resources for Food and Agriculture, the National Information Sharing Mechanism (NISM), which serves as a monitoring tool of the implementation of the Global Plan of Action (GPA), in Republic of Moldova, has been established in 2017. In this context, various activities have been carried out. In order to gather relevant information on state of PGRFA in RM, collaboration between national stakeholders was initiated. As part of the Moldavian National Information Sharing Mechanism on PGRFA, the obtained data were analyzed, compiled, revised, and recorded into the FAO WIEWS Reporting system. Dataset on 1443 accessions stored in the ReGen was published in NISM Reporting system that corresponds to the required information.

Furthermore, FAO WIEWS requests, on a regular basis, updated subsets from all genebanks worldwide. The requested format for these subsets is roughly based on the MCPD standard. The record level data unit is however different, as WIEWS request metadata on stratified groups of genebank accessions, rather than the accession level data have been requested by EURISCO, ECCDBs and SINGER.

In 2018, with the reference to indicator 2.5.1 "Number of plant and animal genetic resources for food and agriculture secured in either medi um or long-term conservation facilities" for Sustainable Development Goals, the data on 6415 accessions conserved ex situ at national level was reported, but in 2019, as a result of database updating the dataset on 6015 accessions was exported in WIEWS database.

Distributed germplasm information system will make updated germplasm information more easily accessible to plant breeders, crop scientists and other users, thus providing better access to plant material.

\section{DISCUSSIONS}

The Republic of Moldova is part of the UN Convention on Biological Diversity of 1995 and ratified its two Protocols - the Cartagena Protocol on Biosafety (2003), including the Nagoya - Kuala Lumpur Supplementary Protocol on Liability and Redress to the Cartagena Protocol on Biosafety and the Nagoya Protocol on Access and Benefit Sharing (2016), and signed International Treaty on Plant Genetic Resources for Food and Agriculture (2001) and the requirement of this official agreements need to be respected. But actually, the lack of easy access to germplasm information at the national level remains an important bottleneck for utilization of plant genetic resources material.

The problem that needs to be solved is insufficient interinstitutional collaboration in the field of exchange of information. Implementation of general information standards on PGR documentation at national level will ensure the interoperability of genebank data sets within institutions holder of ex situ collections in the country. In order to achieve this goal, one of precondition is the existence of easily accessible, good quality and comprehensive data on conserved germplasm. Only the collaboration of all ex situ holder institutions will contribute to the initiation of a unified database at the national level.

Major challenges and constraints of activities in the field of PGR documentation can be summarizes as:

- There is no collaboration between all maintainers of germplasm;

- All relevant information on ex situ collections was not documented in the unique database; 
- The lack of common standard format on collection's information of all institutions involved in PGR conservation;

- Historical gaps in the stored infor mation on PGR;

- Insufficient well-trained staff in documentation of PGR;

- Insufficient financial resources for database maintenance.

At the level of scientific institutions, the capacity of supporting ex situ collections decreases annually, due to the reduction of financing support from the state budget, the lack of human resources, especially the young specialists, and the lack of performance equipment.

The lack of auxiliary staff, especially field workers, as well as those involved in other activities related to the preservation of ex situ collections represents a considerable problem. They are also missing in the field of RGV documentation, and the data on existing collections in each institution were recorded partial, especially in computerized form. There is no collaboration in area of sharing information at national level. Another problem is the professional training of the employees. Thus, it is important to mention the need to train staff in order to make the conservation activities more efficient.

The situation in the Botanical Garden is quite complicated. Supporting of existing ex situ collections requires considerable funding, which, being modest, was significantly reduced. Similar situations are attested in other institutions, which lead to the diminution of PGRFA conservation activities and the loss of accessions from existing collections.

One of the problems of Laboratory for PGR of IGPhPP, is the technical modernization of the block for long-term conservation. One part of the equipment was procured from the SeedNet project in 2007, other part with the FAO support in 2017. However, it is still necessary to solve several technical and organizational moments that cannot be done due to some subjective considerations.

The following priorities for ex situ conservation activities are proposed:

- Support to existing holder institutions of ex situ collections should be strengthened with particular reference to their modernization;

- Regeneration activities should be improved for maintaining the collected germplasm and safeguarding against their loss;

- The support should be ensured in terms of trained staff and finance, particularly for active collections to prevent their loss;

- Ex situ conservation system should be developed with the involvement of local farmers/people so: the collection of indigenous germplasm can be strengthened; and information on local knowledge and practices, as well as information on the uses of indigenous PGR can be gathered, documented and preserved.

ReGen is an information system that aims to document PGR at national level. But in the absence of the national program, there is no interinstitutional collaboration in this area. Most of the information on germplasm collections from holder institutions is not included in this database. Thus, it is necessary to develop an official information-sharing mechanism among the institutions, holders of ex situ collections with the direct involvement of Ministry of Agriculture, Regional Development and Environment that will coordinate the activities related to access and share the information on PGR.

\section{CONCLUSIONS}

1. An integrated approach of the ReGen information system on PGR that includes three basic functional blocks that refer to the existing information on ex situ, in situ/on farm conservation in the Republic of Moldova seems to be the most adequate way to increase the possibility to: manage more effectively the existing information about germplasm collections at the national level; make more easy and available the data that interest breeders and researchers; and use the most useful conservation strategies.

2. The efficient and effective conservation and sustainable use of the world's plant genetic resources for food and agriculture depends on reliable and accessible information about the resource. An evolving international regulatory framework for assessment and sharing of PGRFA benefits in 
cludes the information dimension that needs to be put in evidence worldwide, because "the information determines the value of germplasm collections".

3. Access and sharing of information which are essential for plant conservation research are often lacking and it is essential to solve this situation as soon as possible.

\section{CONFLICT OF INTERESTS}

The authors do not declare any conflict of interest.

\section{ACKNOWLEDGEMENT}

Activities of this research study were performed in the framework of the Project: "Support to the development of National Programme for Plant Genetic Resources for Food and Agriculture in Moldova", Project number: TCP/MOL/3504, jointly funded by FAO. Special thanks to my colleagues from Ministry of Agriculture, Regional Development and Environment, National Agency for Food Safety (ANSA); State Commission for Variety Testing Plant; the National Federation of Farmers from Moldova; from scientific institutions involved in PGR conservation: ScientificPractical Institute of Horticulture and Food Technologies (SPIHFT); the Botanical Garden (Institute) (BG); Porumbeni Institute of Plant Growing (Porumbeni) etc., Selectia Research Institute of Field Crops, and the staff of the Laboratory of PGR of Institute of Genetics, Physiology and Plant Protection, who participated in the realization of this study.

\section{REFERENCES}

1. International Treaty on Plant Genetic Resources for Food and Agriculture. Rome: FAO, 2009. Available from: http://www.fao.org/plant-treaty/en/ [Accessed 20th April 2020].

2. Maxted N, Iriondo J, Dulloo E, Lane A. Introduction: the integration of PGR conservation with protected area management. In: Iriondo, J.M., Maxted, N. and Dulloo, E. (Eds.), Plant Genetic Population Management. UK: Wallingford, CAB International. 2008;1-22.

3. Frison E, Demers N. Building a global plant genetic resources system. In: Roberto Tuberosa, Andreas Grane, Emile Frison Editors. Genomics of Plant Genetic Resources. New York: Springer. 2014;(1):325. doi:10.1007/978-94-007-7572-5

4. The world's online encyclopedia. Information Access. Available from: https://www.encyclopedia. com/ [Accessed 15th April 2020].

5. van Hintum Th, Begemann F, Maggioni L. The European ex situ PGR Information Landscape. In: Maurer L, Tochtermann K, editors. Information and Communication Technologies for Biodiversity Conservation and Agriculture. Shaker Verlag, Aachen. 2008;149-165.

6. Endresen DTF, Knüpffer H. The darvin core extension for genebanks open up new opportunities for sharing germplasm data sets. Biodiversity Informatics. 2012;8:12-29.

7. Dulong de Rosnay M, Guadamuz A. Open Access to Biodiversity Scientific Data: A Comparative Study. 17th International Consortium on Applied Bioeconomy Research ICABR Conference on Innovation and the Policy for the Bioeconomy. Italy: Ravello, 2013:20. Available from: http://creativecommons. org/licenses/by/3.0/_[Accessed: 16th April 2020].

8. Berlin Declaration on Open Access to Knowledge in the Sciences and Humanities. Available from: https://openaccess.mpg.de/67605/berlin_declara tion_engl.pdf [Accessed 18th April 2020].

9. van den Eynden V, Oatham MP, Johnson W. How free access internet resources benefit biodiversity and conservation research: Trinidad and Tobago's endemic plants and their conservation status. Fauna \& Flora International. 2008;42(3):400-407. doi:10.1017/S0030605308007321 [Accessed: 17th April 2020].

10. Bettencourt E. Sources of information on existing germplasm collections. Chapter 8. In: Guarino, L.; Ramanatha Rao. V.; Goldberg, E. (eds.). Collecting plant genetic diversity: technical guidelines. Rome: Bioversity International; 2011.

11.Knüpffer H, Endresen DTF, Faberová I, Gaiji S. Integrating genebanks into biodiversity information networks. In: Proceedings of the 18th $E U$ CARPIA Genetic Resources Section Meeting "Plant Genetic Resources and their Exploitation in the Plant Breeding for Food and Agriculture", 2007:110 Available from: http://vurveucarpia.kios.sk/ abstracts $/ 1$ [Accessed: 17th April 2020].

12. Ling M. et al. Better data, better decisions: increasing the impact of biodiversity information. Published by the Forest Sciences Centre of Catalonia; 2019.

13. Hobern D, Baptiste B, Copas K, Guralnick R, Hahn A, van Huis E, et al. Connecting data and expertise: a new alliance for biodiversity knowledge. Biodiversity Data Journal. 2019;7:1-20. doi:10.3897/ BDJ.7.e33679.

14. Brink M, van Hintum Th, Genebank Operation in the Arena of Access and Benefit-Sharing Policies. Frontiers in Plant Science. 2020;10:1-8. doi:10.3389/fpls.2019.01712 
15. Maurer L, Tochtermann K. Information and communication technologies for biodiversity conservation and agriculture. Shaker Verlag Aachen, 2010.
16. Weise S, Oppermann M, Maggioni L, van Hintum, Th, Knüpffer H. EURISCO: The European search catalogue for plant genetic resources. Nucleic Acids Res. 2017;45:1003-8. doi:10.1093/nar/gkw755

Date of receipt of the manuscript: $26 / 04 / 2020$

Date of acceptance for publication: 20/07/2020 